\title{
The Rise of the US Federal Reserve as a World Monetary Authority: Revisiting the Volcker Shock
}

\author{
Kyuteg Lim
}

In the existing International Political Economy literature, the Volcker Shock has been widely regarded as historical significance in the development of international political economy. Three successive waves of IPE have evolved to highlight it respectively, as a subjugation of the US state to pressures of foreign states, to international financial power, and institutional configurations of US financial power. Without close attention to the particular role of the US Federal Reserve, however, these observations obscure the unprecedented process of a new mode of monetary governance. This paper argues that the Volcker Shock ushered in the rise of the US Federal Reserve as a world monetary authority in a way that the inner-making process of autonomous monetary policy became a new way of governing monetary and financial affairs. The Federal Reserve was able to pursue autonomous monetary policy far away from the economic management of the US government and at the same time to discipline banks in international financial markets. The Federal Reserve eventually established itself as a new kind of monetary authority between US government and international financial markets. This paper contributes to the study of international monetary power.

Key Words: The Volcker Shock, The US Federal Reserve, World Monetary Authority, The US Government, Monetarism, Global Financial Markets

* Research Associate at Peace and Democracy Institute, Korea University. Kyuteg Lim obtained a PhD at Durham University in 2017 and was a Teaching Fellow in International Political Economy at the School of Government and International Affairs at Durham University for the 2017/18 year. He is interested in history of money and finance, and politics of global finance and world money.

I would like to express my gratitude to Hong-Kyu Park and Hyeok Yong Kwon for their generosity and support in the course of completing this manuscript. This manuscript has benefited in particular from access to various research resources, provided by Peace and Democracy Institute, Korea University. Many thanks go to three anonymous reviewers for their helpful comments and suggestions and the editors. 


\section{INTRODUCTION}

The Volcker Shock between 1979 and 1982 has continued to draw scholars of international political economy (IPE). The historical significance of the Volcker Shock is often considered to be a 'restructuring moment' of the relationship between labour and 'finance capital' in the development of neoliberalism (Panitch and Gindin 2009). Dumenil and Levy revisited the monetary event to draw attention to the 'origin' of neoliberalism (2004). The Volcker Shock is understood to offer a 'solution' to the US state struggling to meet social needs with declining fiscal resources by turning to market mechanisms (Krippner 2011). The Volcker Shock is regarded as a significant turning point in the development of US financial capacity by attracting foreign capital into US financial markets (Duncan 2005; Konings 2011; Schwartz 2014). As such, there is little consensus on what the historical event means to the US state, the US society, and international financial markets.

It is possible to identify three 'waves' of IPE literature that, over time and to date, have emerged to offer contrasting analyses of the Volcker Shock. The first wave stressed it in inter-state relations. Robert Gilpin understood its historical significance as a reaction of the US state to the unwillingness of Germany to support the US dollar and import American inflation (1987, 331-332). That is, it was the first time that the US state made an important policy change in response to foreign pressures in the post-war era. In the context of broad discussions around the decline of US power, high levels of inflation experienced in the industrial world were closely associated with the instability of the post-Bretton Woods monetary system, caused by the declining power of the US state (Krasner 1978, 82; Keohane 1982). Regarding the US dollar as a key mechanism of the stable Bretton Woods system, the unstable post-Bretton monetary system led to the conclusion that the US dollar as international money had come to an end (Kindleberger 1976, 35). The static relationship between the US dollar and the US state misled these theorists to identify the driving force of the international monetary system as the declining power of the US state. Consequently, the 1979 monetary shock was primarily understood in an inter-state term.

Without denying the pressures of foreign countries, the second wave of IPE regarded the Volcker Shock as a turning point in the relationship between the US state and international financial markets. The Shock was by and large understood as the US state's submission to the discipline of international financial markets, being forced resultantly to deregulate financial markets (Cerny 1993b; Gill 1993; Helleiner 1994). The powerful force of international financial markets in the 1970s constrained and reduced the role of the state in 'the financial decision- 
making process' (Cerny 1993b, 171). For Stephen Gill, the Volcker Shock was an ultimate sign of how global financial pressures undermined the capacity of the US state to regulate economies (1993, 97-98). Erich Helleiner noted that the Federal Reserve's turn to monetarism was motivated by the desire to restore the confidence of international financial markets and foreign governments in the US dollar, which in turn depended on the ability of the US state to accept austerity measures. That is, the US state was no longer able to pursue its autonomous economic policy and therefore submitted itself to 'the discipline of international financial pressures' (Helleiner 1994, 133). The puzzling question, then, was why the US state, subject to the stringencies of global financial markets, was able to fall further into its current account deficits after the Volcker Shock (see Figure A1).

More recent IPE literature views the turn to monetarism narrowly, as a project of 'finance capital', financial markets, against labour unions (Panitch and Gindin 2008). The Marxist position contrasting labour and capital is central in identifying how high levels of inflation decreased. It began with the Reagan administration's attack on labour unions, and eventually led to not only win the 'confidence of financial markets but also put itself [the US state] in the position to be able to tell other states to likewise address their own balance of class forces' (Ibid, 33). The difficulty of the Marxist approach is to ignore power struggles between investment banks and commercial banks within US financial markets (Hager 2012). More importantly, they do not pay attention to the actual role of the US Federal Reserve in relation to the US government and international financial markets.

The Volcker Shock is recently interpreted as 'a new kind of control [by the Federal Reserve] over the dynamic of financial expansion' (Konings 2011, 131). The Federal Reserve's turn to monetarism involved the process of reconfiguring 'the key parameters of the relation between the US monetary authorities, American finance, and global finance in a way that enhanced rather than diminished the infrastructural capacities and policy autonomy of the American state' (Ibid, 132). Such reconfiguration is identified by: i) an acceleration of financial innovation and the undiminished growth of liquidity creation; ii) social and financial reforms, led by the Reagan administration, which made more options available to the financial markets; and iii) a political willingness to provide an expansion of the Federal Reserve's power over financial market governance (Ibid, 132-135). In consequence, the Volcker Shock's high interest rates sucked funds into the financial markets by 'transforming consumer price inflation into asset price inflation (Ibid, 137). The monetarist turn therefore did not dampen inflationary pressures but 'made them more functional to US 
financial power' (Ibid,139) In moving beyond the state versus market dichotomy, Konings provided nuanced understanding of the monetarist turn as a process of institutional reconfiguration of US financial power.

Nonetheless, the Federal Reserve's new kind of control over the dynamic of financial expansion was not clearly explained. That is, the role of the Federal Reserve is passively seen as being only to re-obtain membership by imposing universal reserve requirements on all depository institutions. It was rather the financial innovation of private banks which responded to the monetarist turn so that nothing changed in the way private banks conducted their financial business. The monetary shock further intensified financial innovation and expanded a liquidity-generating process by drawing money from the manufacturing sector to the financial sect. Indeed, there is no new kind of Federal Reserve control over the dynamic of financial expansion. Without a focus on the act of the US central bank, the significance of institutional configuration is lost in order to understand how the US central bank began to reobtain authority in financial markets. Interpreting the significance of the Volcker Shock as a process of financial market dynamics does not help us to grapple with what the US central bank tried to achieve in relation to the US government and international financial markets.

The core argument advanced by this paper is that the Volcker Shock ushered in the unprecedented rise of the US Federal Reserve as a world monetary authority in relation to the US government and global financial markets. The Federal Reserve's turn to monetary targeting was a new beginning of autonomous monetary governance which not only inflicted a severe damage to both the Carter and Regan administrations but disciplined important actors in financial markets as well. The Federal Reserve protected autonomous monetary policy in ways that the making of the monetary policy was legitimized within and outside the Federal Reserve. Therefore, they were able to persistently stick with the unprecedented approach to monetary targeting, even though there were constant attacks from politicians and social groups on the Federal Reserve and Volcker. The Federal Reserve redefined the social meaning of money in the US society by bringing inflation under control.

The Volcker Shock involved a reassertion of the US Federal Reserve over the dynamic of global financial markets, in particular US domestic money market and the Eurodollar market. The same autonomous monetary policy (monetary targeting) enabled the Federal Reserve to directly intervene into the money markets. The direct intervention of the Federal Reserve aimed to discipline banks by disrupting the valuation of their assets and liabilities. Therefore, banks became forced to pay careful attention to what was decided at the Federal 
Reserve. The internal workings of Federal Reserve monetary policy-making became a new means of monetary governance over the dynamics of financial expansion. The process of disciplining market actors eventually led the Federal Reserve to expand its role as lender of last resort beyond US banks. As such, the Volcker shock should be historicized in a way that the Federal Reserve established itself as a new kind of monetary authority in relation to the US state and global financial markets.

This paper contributes to the study of US state capacity and international monetary power in the IPE literature. It has been widely accepted that the Volcker Shock was a post-war subjugation of the US state to accept austerity measures under the pressure of foreign states and international financial markets, as the first and second IPE waves tell us; the so-called 'neoliberal restructuring.' The role of the US state is characterized as 'retreating' from economic management. US state capacity has since then reduced, while US financial market power has increased. The neoliberal restructuring is fundamentally based on the dichotomous state versus market conception. The binary conception of state and market is seen to derive from the regulatory role of the state in markets. From a Weberian conception of the state, however, Hobson (1997) argues that the state is not a passive entity, controlled by private interests. Rather the role of the state is constitutive of making global financial markets (Seabrooke 2001). In this regard, the driving force of 'restructuring' the US society and financial markets was the US central bank as a state institution and a monetary authority. The dichotomous state versus market conception does not help us understand why the monetary capacity of the US state has continued to increase in the force of international financial markets. The US state has sold its own debt effectively despite its growing current account deficits since the early 1980 s. But most of the IPE literature has focused on deep and liquid US financial markets as a key source of US financial power; that is, market power rather than state capacity. It is not just highly developed US financial markets to attract foreign capital but the linkage between the extended role of the US central bank as an international monetary authority and the primacy of the US dollar in international financial markets validates US debt in particular US Treasury securities as 'risk'- free assets, crucial to the expansion of private international financial markets. This paper shows that the Volcker Shock was neither simply a submission of the US state to the power of global financial markets in order to establish confidence in the US dollar, nor a process of institutional reconfiguration more functional for US financial power. The historical event was the Federal Reserve's attempt to gain control over the key mechanism of global financial expansion: the dynamic force of the US money 
and the Eurodollar market. In this sense, institutional changes termed 'financial deregulations' such as the removal of capital controls, worked to increase the effectiveness of the Federal Reserve's monetary policy to reobtain a monetary sovereignty over the dynamic of international financial expansion. As such, the Volcker Shock needs to be understood not as a decline of US state capacity over international financial markets but rather a rise of US state capacity in governing international financial markets.

International monetary power is understood as a relational concept between countries economically involved in world economy. For example, international monetary power is exercised when a country changes economic policy or behaviour due to its monetary relationship with another country (Andrew 2006, 9). Benjamin Cohen presents two forms of international monetary power in inter-state relations as the power to delay and the power to deflect adjustment costs (2006, 31-50). A core characteristic of international monetary power is who is enforced to adjust toward 'international equilibrium' through a means of exchange rate levels: who pays adjustment costs. In this way, US monetary power is seen to postpone adjustment since 1981 because of the unique status of the US dollar as a key international currency used in market actors and accumulated in foreign central banks (Ibid, 45). Cohen also notes that the international status of the US dollar contains its own downside. Dollar accumulations in foreign central banks mean 'a form of external borrowing by the United States' (Ibid). Foreign creditors would stop lending money to the US state because growing US current account deficits would give rise to a loss of foreign confidence in the US dollar.

Conceptualizing international monetary power as a relational property may be useful to analyze policy changes of countries involved, but international monetary power is narrowly characterized; specifically, international monetary power of the US is inadequately conceptualized. The study of international monetary power does not pay sufficient attention to the relationship between central banks and global finance, in particular the relationship among money, monetary authority and financial markets. The focus on international distribution of adjustment costs at the macro-level ignores a core institution of state capacity, the US central bank, as an international monetary authority at both micro- and macro-levels (e.g. Cohen 2016). The power of international financial markets has been generally believed to increase at the expense of state capacity in economic management since international capital flows have constrained a range of economic policy of a number of countries which have liberalized financial markets from the 1980s. This generalization does not necessarily apply to contemporary US monetary power in global finance. As shown throughout main sections, the dynamic process of global financial 
expansion requires an extension of the role of the US central bank as a world monetary authority. The key source of international monetary power, as Susan Strange (1986) recognizes, is the international primacy of the US dollar which underpins dynamic financial market development. To be precise, the dynamic development of global financial markets has been rooted in the institutionalization of the US dollar as world money across borders since the early 1960 s (Lim 2009).

This paper shows that the essence of international monetary power lies on the capacity of the US monetary authority able to dictate the valuation of the US dollar and dollar assets across borders through the impact of US monetary policy on onshore and offshore money markets. The US Federal Reserve actually provided little ground with banks' interest rate calculation by controlling total banking reserves. The linkage between the US monetary authority and valuation of the US dollar as world money led to an international realization of the US Federal Reserve as a world monetary authority over global financial markets and US government debt as safe financial assets for states and market actors across borders during the Volcker Shock. The Shock is a manifestation of US international monetary power in global financial markets since the repercussion of the US monetarism was globally affected in different parts of the world such as in East Europe and Latin America. Others like Japan increased US dollar holdings in the form of US Treasury securities. The US state may be seen, as Cohen (2016) tells us, to borrow from the rest of the world to avoid adjustment costs. Rather, the infrastructural power of the US dollar enables the US state to issue its own debt, globally accepted to foreign states and market actors across borders. A series of international financial crisis since the Volcker Shock has shown us that international demand for the US dollar and US Treasury securities in particular has not decreased but paradoxically increased, and therefore the role of the US central bank has been further extended, as shown in the recent global financial crisis. As far as the US state is seen as legitimate to US taxpayers, US monetary power is not likely to disappear soon.

From a methodological point of view, this paper does not consider the role of political actors in the process of monetary policy making at the Federal Reserve. First, US monetary policy is decided at each FOMC meeting which excludes political actors and only includes governors, chairman, and presidents of Federal Reserve Banks. Unlike the Bank of Japan which allows political actors to participate in the decision making process of monetary policy without voting power (Gerdesmeier et al 2007), the US Federal Reserve System does not allow any political actor to participate in monetary policy making processes. Furthermore, even though Paul Volcker informed important political actors of 
his plan in the Carter's administration prior to the October operational shift, they could not reverse the decision of the Federal Reserve on monetary targeting. In a US constitutional sense, the US government spends federal budgets, but the US congress decides on government deficit finance and approves the US Federal Reserve to finance it (Axilrod 2011). It is US congress which holds responsibility for the legitimate existence of the US Federal Reserve as a monetary authority. During the Volcker Shock, the US congress supported the US Federal Reserve fighting against inflation by passing the 1980 Monetary Act which required all depository institutions to place more reserves at the Federal Reserve. For these reasons, this paper excludes the role of political actors in the analysis of the Volcker Shock. Rather it focuses on how the Federal Reserve brought inflation under control.

The rest of the paper is organized as follows. The second section of the paper focuses on how the Federal Reserve under Paul Volcker protected its autonomous monetary policy away from the economic management of the US government. The section traces back to the process of centralization of monetary policy at the Federal Reserve in Washington and briefly provides comparative views on the characterization of the Federal Reserve under previous chairmen and Paul Volcker. The section moves on to the analysis of the legitimization of the autonomous monetary policy within and outside the FOMC. The third section concentrates on how the Federal Reserve re-obtains authority over the dynamic force of money markets. The section begins with characterizing the dynamic force of money markets in the late 1970s and explains the impact of the monetary shock on money markets and the creation of offshore monetary space within the US. The section then moves on to explain the extended role of the US central bank beyond US banks. The fourth section explains why the Federal Reserve went back to the traditional monetary policy in mid-1982. The last section summarizes arguments and offer implications on central banking.

\section{THE US FEDERAL RESERVE AND THE US GOVERNMENT}

The Volcker Shock ushered in an unprecedented autonomy of monetary policy far distanced from the economic management of the US government. Autonomous monetary policy began with the appointment of Paul Volcker as new chairman. The 1979 October operational shift to targeting money supply instead of targeting interest rates led to the historically unique process of repositioning the Federal Reserve as a monetary authority in relation to the US government. As far as the autonomous monetary policy was legitimized, the 
Federal Reserve was able to exploit uncertainty monetary targeting created. Before going over the detailed process of the autonomous monetary policy, it is necessary to trace back to the centralization of power under the Federal Reserve System $^{1}$ (hereafter the Federal Reserve) in Washington.

What enables Paul Volcker to implement a dramatic operational shift to targeting monetary growth in October 1979 is that prior chairmen centralized the power of the Board of Governors and its Chairman under the Federal Open Market Committee (hereafter FOMC), previously dominated by the Federal Reserve Bank of New York. Chairman McChesney Martin between 1951 and 1970 undertook important steps in centralizing power in Washington. First Martin ended the FOMC's Executive Committee, dominated by the New York Federal Reserve Bank. All members of the FOMC began to present their opinions and to discuss all policy options in the making of money policy from the second half of the 1950 os (Meltzer 2009, 263). Second, the Board of Governors took over important aspects of open market operations under the FOMC. In the early 1960s, when the Federal Reserve attempted to operate foreign currency swaps with foreign central banks, who held responsibility for foreign currency operations within the Federal Reserve System was debated at a FOMC meeting (FOMC 1962 March): the international aspect of open market operations. Eventually, the Board of Governors ended the New York Reserve Bank's major role in foreign currency operations. Furthermore, other important responsibilities such as budgeting were conferred upon the Board, and the Board's staff increased from 608 to 790 between 1963 and 1968 (Meltzer 2009, 493).

The power of the chairman and the Board of Governors was further consolidated with the establishment of two policy documents: green and blue books date back to the mid-1960s. The policy documents are the Federal Reserve's confidential briefing documents which are distributed ahead of each FOMC meeting. The green book provides an analysis of the US economy and international economy. It contains a huge amount of statistical resources devoted to economic projections. The blue book concentrates on money market conditions

\footnotetext{
${ }^{1}$ The Federal Reserve System is the central bank of the US. The Federal Reserve System constitutes the Federal Reserve Board of Governors in Washington and twelve Federal Reserve Banks in different regions across the US. The Federal Open Market Committee is the body of the Federal Reserve System that sets national monetary policy. The FOMC makes all decisions regarding the conduct of open market operations, which affect the federal funds rate (the rate at which banks lend to each other). The FOMC consists of twelve voting members - the seven members of the Federal Reserve Board, including its chairman, and the president of New York Reserve Bank and the four presidents of the remaining eleven Reserve Banks on a rotation basis (Mayer 2001, 144)
} 
and provides alternative policy options for FOMC consideration (Deane and Pringle 1994, 222). The latter in particular helps the FOMC to consider whether monetary policy toward tightness or ease needs to be implemented during the period between FOMC meetings. The interpretation of the numerical data in the blue book is decisively determined by the Board staff. Thus it enhanced the power of the Board against the Federal Reserve Bank of New York (Axilrod 2011, 46). The interpretation of any FOMC policy decision and its implementation are held in the hands of Board Governors and its chairman. According to Sherman Maisel, as a governor between 1965 and 1972, the chairman could wield 'about 45 percent of the total power relative to the other board members' in the FOMC (quoted in Deane and Pringle 1994, 228). David Jones described the culture of the Federal Reserve as "chairman-centered" $(1991,53)$. Martin ensured that the central power of the Federal Reserve System, the making of monetary policy under the FOMC, rested on the Board of Governors and its chairman in Washington (Axilrod 2011, 51).

In the late 1970s during which inflation was rapidly rising, the credibility of the Federal Reserve was severely undermined by G. William Miller as new chairman. President Carter appointed him to succeed Arthur Burns on March 8 1978. As a former corporate chief executive of Texton, Miller was neither trained in economics nor familiar with monetary policy, even though he was one of the board members of the Federal Reserve Bank of Boston (Axilrod 2011, 77). Given a lack of expertise in monetary policy and technical monetary matters, the new chairman had to learn monetary terms and needed to listen to opinions of fellow Board members highly experienced in monetary affairs (Deane and Pringle 1994, 231). This was a sign of weakness in his leadership in tackling high inflationary expectations for which his expertise and decisive leadership was needed most at the Federal Reserve. When a chairman is seen as weak, the coherence of the FOMC monetary policy making is undermined (Axilrod 2011, 228). Miller brought his corporate management style to the FOMC. He placed 'a three minutes egg timer on the table at board meetings to limit the often rambling discourse' (Treaster 2004, 51). At a June FOMC meeting in 1978, Miller voted against the majority who wanted to raise the discount rate. His stance suggested that the chairman was not serious about controlling inflation (ibid). He could not effectively lead the FOMC and the Board with him (Dean and Pringle 1994, 228). He lost his chairman status within and outside the Federal Reserve. Miller was the last non-professional Federal Reserve chairman. Since then, the Federal Reserve has had strongly professional leadership, first from Paul Volcker, then Alan Greenspan. All of them are trained in economics and possess intellectual expertise in monetary policy. 
Under pressure of climbing inflation and the declining credibility of the Federal Reserve, Carter appointed Paul Volcker as new chairman in August $1979^{2}$. The Federal Reserve under the new chairman began the unprecedented process of autonomous monetary policy away from the government. President Carter "purchased" credibility of Paul Volcker (Hall 2008, 177; Johnson 1998, 176). Carter initially contacted some people like David Rockfeller to consider the Federal Reserve chairing post. They all turned down Carter's offer and instead recommend Paul Volcker (Treaster 2004, 60). Anthony Solomon, undersecretary of the Treasury for monetary affairs, suggested Paul Volcker because he reasoned that Volcker not only had the technical understanding of monetary policy, but could lead the difficult decision-making process of the FOMC effectively and articulate monetary policy decisions to the public as well (Deane and Pringle 1994, 99). None doubted his intellectual credentials inside and outside the Carter administration, but the Carter administration concerned that Volcker would not be a team player (Axilrod 2011, 231). Unlike Miller, Volcker possessed intellectual expertise and experiences in monetary policy. He served as undersecretary of the Treasury for international monetary affairs in the early 1970s and president of the Federal Reserve Bank of New York from 1974 until 1979 (Mayer 2001, 192). He was supported by three prominent Board members such as Henry Wallich, Charles Partee and Lyle Gramley within the Federal Reserve (Bartels 1985, 38). His intellectual competence and professional experiences in monetary policy seemed to obtain strong leadership in the FOMC and the Federal Reserve (Hall 2008; Goodfriend 1986).

The Federal Reserve's traditional approach to interest rates targeting could not have impact on inflationary expectations. When Volcker came to office in early August 1979, like previous chairmen, who attempted to control inflation from the mid-1970s but shied away from monetary tightening ${ }^{3}$ (Burns 1987, 692), the Federal Reserve under Paul Volcker initially attempted to target interest rates through either the discount rate ${ }^{4}$ or open market operations ${ }^{5}$.

\footnotetext{
${ }^{2}$ Inflation rate was reaching about 12 percent, and the real return on Treasury bills as a barometer of federal funds rates was negative (Meulendyke 1998, 193)

${ }^{3}$ They did not implement monetary policy far distanced from the economic management of the US government. The relationship between the Federal Reserve and the US government is ambiguous during the 1970s (Woolley 1984). The US Federal Reserve seems to be independent but not autonomous. That is, attempts to control inflation through the traditional monetary policy were not intended to inflict a severe damage to the economic management of the US government in the 1970s.

${ }^{4}$ The rate at which the Federal Reserve would charge banks borrowing at its discount window

${ }^{5}$ The Federal Reserve purchases and sales US government securities to provide a certain level of reserves required to achieve the desired target of interest rates (Mayer 2001, 23)
} 
However, Federal Reserve watchers, hired by big banks, were able to speculate on movements of interest rates by monitoring the action of the Federal Reserve in open market operations. The signal the new chairman sent was not going to change a course of monetary policy (Treaster 2004, 148). Expectation on interest rate movements encouraged banks to speculate on the value of the US dollar, financial assets and commodities in various financial markets, and could not dampen inflationary expectations in the public (Federal Reserve Bulletin 1979). Volcker and board members were not satisfied with the traditional approach. Precisely they informally decided to turn to monetary targeting on September 28, 1979 (Johnson 1998, 176), before Paul Volcker visited the Belgrade meeting of the International Monetary Fund in the following week during which it was assumed that he made up his mind toward monetary targeting under pressures of foreign states or international financial markets, as the first and second waves of IPE tell us.

Rather, they turned to targeting total banking reserves to create uncertainty in inflationary expectations in October 1979. This October operational shift led the Federal Reserve to purse an unprecedented process of autonomous monetary policy far distanced from the economic need of the US government. Krippner (2007) observed that the reserve strategy was a political strategy to deflect the public from blaming the Federal Reserve for high levels of interest rate in the image that markets determined interest rates; social and political reaction to high interest rates was muted (489-90). However, the operational shift was more than simply a political cover. The sphere of macroeconomic policy is in general less affected by domestic politics and the public's opinions (Odell 1982; Hall 1993). More important, the traditional interest rate management was kindling a flame in inflationary expectations embedded in the public's belief in political and economic progresses in the post-war era (Burns 1985). The concern with the inflationary flame was made worse by linkages between the dynamic force of the Eurodollar market and the US money market (Kelly 1977; Hawley 1987). Federal Reserve officials were deeply concerned with the impact of the expansionary force of the Eurodollar market on the US dollar, US inflation and the Federal Reserve (Wallich 1979; Frydle 1979-80). The problem of monetary linkages between US inflation and the offshore money market will be detailed in the next section. The Federal Reserve under Paul Volcker turned to targeting monetary reserves intended to create uncertainty: high but volatile interest rates. Inflationary expectations were widely held in businesses, labour unions, consumers in construction and housing sectors, and banks in money and financial markets (Federal Reserve Bulletin 1979). The October operational shift was intended to introduce 'a new uncertainty into the market . . . the new 
uncertainty will have the effect of cooling the speculative activity and perhaps have an impact on those demands for credit that are based purely on inflationary expectations' (Rice, quoted in FOMC 1979 October, 22). As closely looking at monetarist experiences in Germany, Volcker understood that monetary targeting would serve the interests of discipline domestically and internationally, and that they were intertwined (Johnson 1998, 178), as far as the new operation procedure continued to be pursued over time.

From late September 1979, Volcker began to outline his plan (monetary targeting) to William Miller, secretary of the Treasury, and Charles Schultze, chairman of President Carter's Council of Economic Advisers (Mayer 2001, 193). They worried about the negative impact of monetary targeting on President Carter's re-election in the following year. Furthermore, the monetary plane would induce 'uncertainty and inflexible monetary policy' (Treaster 2004, 155). Rather than the monetary plan, Miller and Schultz suggested a 2 percent increase in rates which President Carter would agree on. However, uncertainty was exactly what the Federal Reserve aimed to create in a way that controlling money supply would induce volatile interest rates unexpectedly. Volcker implemented monetary targeting to surprise the public and markets despite protests from the White House about the damage to Carter's re-election chances (Bartels 1985, 38).

The question becomes how the Federal Reserve was able to persistently maintain the autonomous monetary policy for two and a half years, if the monetary targeting was more than a political cover. In 1978, as president of the New York Federal Reserve Bank, Volcker understood that the key means to dampen inflationary expectations was to maintain announced monetary targets consistently over time $(1978,332)$. The answer rests on the legitimization of monetary policy making within and outside the Federal Reserve in several important ways. First, dissenting views within the FOMC were managed in a way that consensus building was prioritized toward uncertainty over other means. There was the policy debate on whether the Federal Reserve wanted to go back to the traditional monetary policy or stick with the present policy at several times between October 1979 and August 1982. At an April 1980 meeting, FOMC members such as such as Partee, Rice and Roose, concerned about volatility of interest rates and a fall into economic recession, in particular in the housing and auto-related sectors of the economy (FMOC 1980 April, 22). However, Volcker argued that the only reason for the present operating target was 'the nature of uncertainty it created'. He went on to say that the economy was not in rapid recession and that 'the most important objective of the Federal Reserve today is to restore credibility in our willingness and our ability to stick with a long-range 
policy and not change the course' (Ibid, 25-26). This kind of the debate also occurred in September 1980 and February 1981 (FOMC 1980 September; FOMC 1981 February). Different views on the monetary target were allowed to express their particular concerns, reflecting on geographical economic situations, affected by the money control. However, the majority of the FOMC members were convinced that control over inflationary expectations was not to reverse its present operating approach until a clear sign of economic recession. The public still suspected the seriousness of the Federal Reserve toward inflation control so that reversing the operational procedure would inflame inflationary expectations again. This point was emphasized by the chairman at each FOMC meeting. In this way, the FOMC was able to stick with the present operation and to make one voice consistently heard to the outside world.

Second, the FOMC's pragmatic approach to monetarism provides room for policy adjustment to developing monetary conditions. At each FOMC meeting, officials decided to target the level of monetary growth, the level of M1, M2 and M3. In particular, they paid close attention to MI as a policy guide. It does not mean that they succeeded in controlling total banking reserves; they actually failed to meet the desired targets (Greider 1987; Mayer 2001; Krippner 2011). What the quantitative approach to monetary targets provided was that 'the statistical basis for determining the target for reserve aggregates consistent with the FOMC's policy decision entailed considerable leeway for staff judgement' (Axilrod 2011, 91). The commonly shared quantified data provided a legitimate basis for understanding and adjusting to monetary conditions. FOMC members consistently monitored and assessed interactions between the application of monetary targets and changing economic developments; in Johnson's term $(1998,6)$, "learning while governing." They were able to adjust the range of the monetary target if new data came along. Two episodes - the summer of 1980 and the period between late 1981 and early 1982 - discredited the guiding measure of M1 as the controlling monetary aggregate. In April 1980, M1 was rapidly shrinking (FOMC 1980 April). More than 17 billion dollars disappeared (Greider 1987, 194). FOMC members were puzzled by the dramatic and unexpected decline in the money supply. It raised a new question: what should monetary targeting set the proper level of M1 to be? The Federal Reserve bought government securities and injected a huge amount of new money $-\$ 5.4$ billion - into the banking system. From that point, M1 grew rapidly and bank lending also increased over the next few months (Greider 1987, 201-206). If demand for reserves exceeded the target of monetary growth established at the FOMC, additional reserves through open market operations were not supplied (Krippner 2011, 117). In this way, they continued to stick with the operating method by 
adjusting the range of monetary reserves consistent with developing monetary conditions. Despite Carter's 1980 credit control intervention, the Federal Reserve's monetary actions were remarkably consistent with its announced monetary targets (Johnson 1998, 181). Indeed, Volcker was satisfied with the progress of monetary developments consistent with monetary targets during the year of 1980 as a whole (Federal Reserve Bulletin 1981). Unlike monetarists who believe in a consistent level of monetary growth, Federal Reserve policymakers held a pragmatic approach to monetary targeting, as demonstrated above. They held confidence in statistical data but made monetary targets adjustable to developing monetary conditions.

The sphere of monetary policy making is politically sensitive in nature. It was hard for any social group or politicians to intervene into the making of monetary policy under the FOMC. It was no denial that FOMC members made highly informed decisions toward monetary targeting. Green and blue books contained an enormous amount of statistical data regarding financial markets, the US economy and international economy. The FOMC had to swallow a great deal of information before making a policy directive (Deane and Pringle 2004, 222). During the monetary shock, even though there were constant attacks from individual politicians, small businesses and labour unions, affected by the restrictive monetary policy, on the Federal Reserve, the US monetary authority was little challenged (Bartels 1985). Congress supported the Federal Reserve's fighting against inflation by passing the 1980 Monetary Act, which in part helped the Federal Reserve to 'take stronger action than we probably could by the other technique (FOMC 1980 March, 19). Monetary policy can have a significant effect on wealth distribution in society (Kirshner 2003; Ingham 2004; Hall 2008). If monetary policy was pursued to achieve inflation less than 10 percent, economic growth would be higher (Kirshner 2003). The key concern would be how to maintain inflation between 3 percent and below 10 percent with better economic outcome. Indeed, politicians are limited to intervene in the decision-making process of monetary policy because short-term political gains would lead to monetary disorders which disrupt the healthy process of economic transactions. More important, the impact of 'monetary policy is so comprehensive' that the attempt of any social groups or politicians to influence monetary policy would be over-politicized (Johnson 1998, 6). Thus, many democratic governments have decided to depoliticize monetary policy by placing the making of monetary policy in the hands of unelected officials with long tenures (Blinder 1998, 56).

Furthermore, Federal Reserve officials protected their monetary policy through active involvement of public communications. Their engagement in public communications was not simply rhetoric. The Humphrey-Hawkins Act 
of 1978 required the chairman of the Federal Reserve to testify the explanation of monetary policy decisions before Congress twice a year (Greider 1987, 96; Fischer 1994, 293). It was rather 'an empty ritual' because relevant policy explanation was avoided (Blinder 1998, 29). However, the public testimony served two important roles. First, it allowed the Federal Reserve to communicate effectively to the public and markets by demonstrating the seriousness of monetary targeting in order to influence inflationary expectations. In December 1979, Volcker said before Congress that 'in changing the emphasis (the monetary target), we necessarily must be less concerned with day-to-day or week-toweek fluctuations in interest rates because those interest rates will respond to shifts in demand for money and reserves' (Federal Reserve Bulletin 1979, 960). The seriousness of the Federal Reserve was further improved by the Reagan administration's attack on labour unions in August 1981 (Gregory 1985, 39). Federal Reserve officials also justified the restrictive monetary policy effectively. The chairman actually "went around the country giving speeches. He always made a point of stressing that the Federal Reserve continued to stick to the tight monetary policy (Axilrod 2011, 99). In February 25, 1981, Volcker explained technical details of the monetary policy such as measures of monetary aggregates in reference to the established monetary target during the previous year as a whole (Federal Reserve Bulletin 1981 March, 237). Without confidence in statistical data collected, Federal Reserve officials would not demonstrate what they found in public. They even provided "seminars" for interested outside experts and economists (Ibid, 238). Thus, they effectively justified the restrictive monetary policy in the eyes of the public. The Federal Reserve conducted public communications in ways that protected its own policy and exploit uncertainty at the same time. The combination of policy actions and rhetoric worked to dampen inflationary expectations (Greider 1987, 41).

Under the Reagan administration, the Federal Reserve continued to maintain restrictive monetary policy (high levels of interest rates) even after it brought down inflation to around 5 percent in mid-1982 (Krippner 2007, 492). One important reason was that Federal Reserve officials were concerned with possibility of inflationary resurgence (FOMC 1982 June-July, 7). The economic policy of the Reagan administration was at odds with the Federal Reserve under Volcker. The US Treasury was home to monetarists and supply-side economists (Axilrod 2011, 102). These economists were not interested in the details of monetary policy operations. The administration provided tax cuts to businesses and increased budget deficits (Johnson 1998, 186). Chairman Volcker persistently spoke against budget deficits which would instigate inflationary psychology (Greider 1987, 482-506). Top officials in the Reagan administration 
were calling for Volcker to resign in 1982: his term was expiring in 1983. Donald Regan, secretary of the US Treasury, made harsh comments such as "tyranny" on Volcker (Treaster 2004, 173). Berly Sprinkel, undersecretary of the Treasury for monetary affairs, did not simply believe that the Federal Reserve alone held control over the importance of money supply (Deane and Pringle 1994, 103). Despite all these attacks from the Reagan administration, Volcker was reappointed by President Reagan in August 1983.

\section{THE US FEDERAL RESERVE AND FINANCIAL MARKETS}

The Volcker Shock was not only about autonomous monetary governance distanced from the US government but a reassertion of monetary sovereignty as well over the dynamic of global financial markets, underpinned by US dollars. The same autonomous monetary policy (monetary targeting) enabled the Federal Reserve to regain control over the key mechanism of global financial expansion: the US money market and the Eurodollar market. The Federal Reserve directly intervened into the money markets by unsettling the valuation of banks' assets and liabilities. The Federal Reserve began to extend its role by opening privileged access to a form of government debt, the most transferable of all dollars, to any US-based depository institutions well beyond US banks. Thus, the Volcker Shock was a fresh step in the process of the Federal Reserve extending its role beyond the US market. It is necessary to characterize the dynamic force of US domestic money markets and the Eurodollar market, causing a deep concern for Federal Reserve officials prior to the Volcker Shock.

The exponential growth of the Eurodollar market in the late 1970s deeply concerned Federal Reserve officials with its impact on the weakness of the US dollar, US inflation and the US central bank. From early 1979, the US Treasury and the Federal Reserve began to initiate international cooperation to regulate the Euromarkets. Anthony Solomon, undersecretary of the US Treasury, suggested that central banks impose reserves on banks operating in the Eurodollar market (Hawley 1984, 152). In April 1979, William Miller, chairman of the Federal Reserve, put forward the robust proposal that all BIS members be required to impose reserves on Eurodollar deposits at their own banks operating offshore (Dale 1984, 27). The attempted reserve obligation showed a clear concern over the expansionary tendency of the Eurodollar market as being a source of the dollar crisis: the weakness of the dollar and its associated inflation. However, the Eurodollar reserve proposal faced strong opposition from foreign central banks such as the Bank of England (Ibid, 28) and from the US banking 
community (Helleiner 1994, 137). The reserve requirement seemed to be practically infeasible (Hawley 1984). Henry Wallich, a governor of the Federal Reserve, argued that reserve requirements would derive Eurodollar businesses from London to other markets $(1979,21-24)$. The growth of the offshore money market in the late 1970 s was 25 percent annually, whereas German money markets were growing at about 10 percent (Frydle 1979-80, 19). The Eurodollar market would 'overtake the creation of domestic credit within a foreseeable period' (Hawley 1984, 138). Unlike economists who viewed the Eurodollar market as a recycling mechanism, Federal Reserve officers were seriously concerned with the rapid growth of the Eurodollar market and its impact on the US dollar, US inflation, and the monetary policy of the US Federal Reserve (Wallich 1979; Frydle 1979-80).

Closely linked to the Eurodollar market, the US money market experienced a dramatic growth during the 1970 s due largely to liability management of US banks. With regulatory relaxation on deposit rates in the early 1970s, US banks issued a large amount of Certificates of Deposit (hereafter CDs). Unlike traditional (time) deposits, which were illiquid until maturity dates, CDs were negotiable and could be turned to liquid cash within a short period of time (Einzig and Quinn 1977, 32). CDs enabled US banks to produce more money (liabilities) at a given level of capital. As Walter (1991) and Konings (2008) stressed, banks became no longer passive deposit takers and active to make money markets for their own good. The US money market, fluctuating at around $\$ 1$ billion along with the low volume of CD issuance during the 1960s, experienced a dramatic growth from $\$ 7$ billion in 1970 to $\$ 56.5$ billion in 1975 (Kelly 1977, 129). The CD became the 'leading money market instrument in the US market' (Versluyen 1981, 74). The dynamics of domestic and offshore dollar markets posed a challenge to the Federal Reserve's traditional monetary policy: interestrate targeting. Its traditional monetary policy was not making any difference to the dynamic force of the money markets. More specifically, the daily purchase and sale of US government securities for short-term interest rate management was not having real effect on the deteriorating terms of dollar-based contracts in the 1970s. The Federal Reserve was failing to maintain the credibility of the US dollar, crucial to its raison d'être as a monetary authority. The US monetary authority should have acted to regain its firm control over the monetary forces.

The October operational shift in 1979 was a direct action of monetary sovereignty to regain control over money markets. After consulting with Federal Reserve officials, Peter D. Sternlight, Manager of the Open Market Desk, did nothing to reassure government securities traders as to 'what a proper interest rate was for a Treasury bill or a government bond' (Greider 1987, 128). It did 
not mean that interest rates were completely ignored, but the framing of widely fluctuating interest rates was intended to affect the way they were set by the market. Unlike the traditional interest rate management, the new operational approach to monetary targeting created uncertainty, volatile interest rates, as emphasized in the previous section. Volcker said at a Federal Reserve meeting that 'market participants are living with fragile expectations and inspired rumour and all the rest from day to day' (FOMC 1979 October, 4). 'People in markets are nervous enough so that policy, for the first time, is beginning to bite' (Volcker quoted, in FOMC 1980 March, 7). Although the FOMC initially established a four percent range for the federal funds rate at its October meeting, the range of interest rate was substantially widened (FOMC 1980 February). For example, the federal funds rates fluctuated between the highest end of 20 percent and the bottom of 8 percent between October 1979 and March 1980. The volatility of short-term rates was intended to be determined by how FOMC members judged progresses and conditions of the monetary target, as discussed in the previous section.

Uncertainty the US monetary authority created provided market actors with little ground to foster their perceived conception of interest rates in any market reality. The confidence of banks in interest rate calculation dramatically dissipated. Market actors could only predict interest rate movements on publications offered by the Federal Reserve. But publications were often vague and unpredictable. For example, the Federal Reserve published the data of M1 weekly, and the weekly information became the primary focus of market operators (Smith 1987, 131). But the data available did not guarantee their market speculation since the targeting of M1 was widened and necessarily brought about unpredictable short-term interest rates. Big banks which speculated on the value of the US dollar, financial assets and commodities like gold, suffered enormously (Greider 1987). They now needed to pay careful attention to the intentions of the Federal Reserve enunciated at each meeting of the FOMC (Smith 1987). This was a new mode of monetary governance initiated by the Federal Reserve in the way that the process of Federal Reserve monetary policy making under the FOMC tended to influence banks' lending and investment decisions.

With monetary targeting, the US monetary authority undertook one further important measure against big banks. It 'placed a special marginal reserve requirement of 8 percent on increase in managed liabilities of larger banks (including US agencies and branches of foreign banks) because that source of funds, which is not included in the usual definition of the money supply has financed much of the recent excessive builup in bank credit (Federal Reserve 
Bulletin 1979, 960, emphasis added). This measure was a clear sign to large banks to be cautious toward their liability management. The reserve measure was later extended to the idea of universal reserve requirement on all depository institutions in 1980. The combination of unpredictable interest rates and the extra reserve requirement was motivated to dampen the speculation of big banks in various financial markets. Thus, the October 1979 operational shift can be seen as the start of a process of the Federal Reserve reasserting itself as a monetary authority over financial markets broadly and money markets more specifically. The US monetary authority aimed to discipline market actors by intentionally unsettling the valuation of their assets and liabilities.

The Volcker Shock had direct impact on the international money market. As discussed above, the Eurodollar market was largely underpinned by US dollars. More specifically, international dollar loans during the 1970s were distributed on the basis of renewable rates, determined by the Eurodollar market (Mendelsohn 1980, 71). They became subjected to uncertain money market rates, dictated by the Federal Reserve's policy change. High levels of Eurodollar rate were fed into the premium cost on the international loans and increased the dollar debt burden of developing countries, which had borrowed heavily from the Euromarkets during the 1970s (BIS 1981, 1982). Short-term volatile rates in the Eurodollar market were further reinforced by the tight monetary policy of foreign central banks such as the Bank of England (Smith 1987) and German and Japanese central banks (BIS 1980, 106). From late 1981, highly unstable short-term interest rates intensified the uncertainty of the Eurodollar market and began to increase the dollar debt burden of sovereign borrowers. Dollar debts owed to developing countries started to be rescheduled significantly; 'more than $\$ 2$ billion for Poland and more than $\$ 4$ billion for Turkey' (Kreicher 1982, 20).

In late 1981, the creation of International Banking Facilities (IBFs) played a part in reducing the impact of the offshore money market on US inflation by making a monetary spatial distinction between the US sovereign monetary space and IBFs. The original plan of IBFs was to restrict banking regulations such as detailed information of financial statements, transactions and owners of banks (Hawley 1984, 156). The Federal Reserve, however, due to the opposition of foreign central banks and private banks, modified the regulations and imposed other limitations which did not apply to foreign branches of US banks in offshore money centres. In particular, the Federal Reserve was concerned with 'the effect that the adoption of such proposals [IBF proposals] would have on the conduct of monetary policy and competition among groups of US banks' (Key 1982, 566). IBF banks, like being in the Eurodollar market, were exempted for reserve requirements and interest rate ceilings (Key 1982; Chrystal 1984). The Federal 
Reserve put limitations on activities of IBFs, differentiated from domestic money markets in several ways. First, IBF depositing and lending were restricted to non-US residents. Second, 'the minimum transaction with an IBF by a nonbank customer is $\$ 100,000$ which limits the activity of IBFs to governments, major corporations or other international banks'. Finally, the issue of negotiable instruments such as CDs was not permitted due to the maintenance of the separation between IBFs and the domestic money markets (Chrystal 1984, 6-7). These limitations placed on IBFs show that the principle concern of the Federal Reserve was to distinguish IBF accounts from domestic banking accounts in the US. Indeed, IBFs attracted many US banks from the Eurodollar market (Key 1982) and from other offshore centers such as the Cayman Islands and Nassau in the Bahamas (Strange 1986, 50). By the end of 1983, IBFs represented about 8 percent of the offshore money market (Chrystal 1984, 9).

The Volcker Shock led the Federal Reserve to eventually extend the role of lender of last resort beyond US banks. It opened privileged access to a form of US government debt, the most transferable of all dollars, directly issued by the Federal Reserve, for foreign banks as long as they were based in the US market. The 1980 Monetary Control Act subjected all depository institutions to universal reserve requirements so that the Federal Reserve could obtain an extended control over them. The significance of this measure did not lie in the increased total banking reserves at the US central bank. It was rather expected that total reserves would be $\$ 15$ billion down (Timberlake 1985, 100; Greider 1987, 160). The impact of the universal reserve requirement increased the costs of holding reserves, in particular for small banks and thrift institutions, whereas member banks increased their profits (Greider 1987, 160-165; Allen and Wilhelm 1988).

Since all depository institutions were subject to reserve holdings at the US central bank, all US-based foreign banks were entitled to access the discount window and borrowing privileges as Federal Reserve member banks. This held 'regardless of whether the institution [was] owned by US or foreign residents and regardless of whether it [was] a branch or affiliate of a foreign institution' (Guttentag and Herring 1993, 19). The privileged openness to the most transferable of all dollars was particularly attractive to international banks operating outside their country of origin, since the US dollar at the Federal Reserve was the most liquid money at money markets at home and abroad. From the early 1970s, US government securities in particular US Treasury bills were regarded as 'risk'-free assets in emerging global financial markets (Lim 2019). US government securities became more valuable in the face of international debt crisis since US government debts were now the most-sought after debt. The tight monetary policy of the Federal Reserve actually increased the global demand 
of US financial debts in general such as US mortgage securities (Duncan 2005, 106) and US government debts more specifically (Greider 1987, 561-563).

The comprehensive openness of the US central bank's discount window to all US-based depository institutions necessarily broadened the conception of collateral for the supply of dollar liquidity. Collateral of a troubled bank was traditionally seen as sound, but often political, for the Federal Reserve to provide dollar liquidity immediately to the bank (Kindleberger 1978, 165-181; Spero 1980, 148). The 1980 Act expanded 'the eligible collateral provision for Federal Reserve notes outstanding to include the fully guaranteed obligations of a foreign government or the agency of a foreign government as well as any financial assets that may be purchased by Reserve Banks' (Timberlake 1985, 99). Federal Reserve money could be issued specifically for political objectives or for rescuing any type of a financial institution, regardless of whether their collateral was viewed as suitable for Federal Reserve money or open market operations. The widened version of collateral provision for and privileged access to Federal Reserve money further increased the attractiveness of US debts in the round, since the US dollar accessible to the central bank's discount window was important to the private practice of issuing dollar debts and transferring them outside the US market, while the Federal Reserve increased its potential burden for the supply of dollar liquidity in the future. With the onset of the Latin American and East European debt crises, foreign investors were attracted to various US financial debts for safety and high interest rates.

\section{THE RETURN TO THE TRADITIONAL MONTARY POLICY}

In the spring of 1982, the Federal Reserve faced three intertwined problems. First, the basic measure of M1 as a monetary target completely broke down. From late 1981, M1 growth had been well above its target. In early 1982, the assumed link between monetary growth and real economic activities completely broke down due to unexpected monetary growth in spite of US economic recession (FOMC 1982 May, 29-30). This confirms that the mechanistic relationship between money and real economic activity could not fundamentally be established: money was more than a neutral medium of exchange in facilitating real economic transactions. Rather, what constitutes money essentially is a social relation of credit and debt measured in a money of account (Ingham 2004; Hall 2008). Money as a social relation of credit and debt has developed independently of the process of real economic processes such as in production and trade (see Ingham 2004; Wray 1998 for more detail). Frank 
Morris, a member of the FOMC, acknowledged that 'M1 no longer provided a reliable guide for steering interest rates lower' (quoted in Krippner 2011, 121).

Second, the US economic recession would be made worse if the Federal Reserve continued to tighten monetary policy. Since inflation came down to around 5 percent in mid-1982, monetary policy toward ease was necessary to recover economic recession with caution on resurgence of inflation. Lastly, the impending international debt crisis was rapidly developing with regard to Latin American countries (FOMC 1982 June-July). Federal Reserve officers like Frank Morris, Anthony Solomon and Lyle Gramley, argued that the Federal Reserve must abandon monetary targeting regardless of what M1 or monetary aggregates indicated. From 1 July 1982, the Federal Reserve began to loosen its grip on banking reserves. As more money became available in the US economy, interest rates decreased. Falling but still-high interest rates revived the financial markets, such as the stock market and the bond market (Greider 1987, 537). Summer 1982 was thus a turning point for the Federal Reserve to go back to the traditional monetary policy: the targeting of interest rates. The experiment of pragmatic monetarism was officially abandoned (FOMC 1982 June-July, 30). Even though the Federal Reserve failed to control monetary aggregates during the Volcker shock, it dictated the valuation of banks' debts and credits by creating market uncertainty.

The Volcker Shock consequently transformed the US economy into the world's consuming economy by attracting foreign capital into the US Treasury market and mortgage debt markets: $\$ 85$ billion in 1983, $\$ 103225$ billion in 1984, $\$ 129$ billion in 1985 and $\$ 221$ billion in 1986 (Krippner 2011, 101). The foreign capital contains not only private savings from surplus countries like Japan (Norville 1998,117 ) but, more importantly, foreign monetary authorities enthusiastically purchased both US Treasury debts and US government agency debts such as 'mortgage securities issued by the Government National Mortgage Association (Ginnie Mae), the Federal National Mortgage Association (Fannie Mae), the Federal Home Loan Mortgage Corporation (Freddie Mac), and the Farmers Home Administration' (Duncan 2005, 106). Even though the Fannie Mae and Freddie Mac debt was not directly guaranteed by the US government, it was believed that the US monetary authority would intervene in the case of default (Ibid, 107). The shift of capital flows from the Eurodollar market into the US debt market indicated that the purchasing power of the US public (with the strengthening of the US dollar and the massive supply of money) enabled the US economy as a whole to become a world consumer society (Schwartz 2014, 70). After the Volcker Shock, the US economy fell into a deeper current account deficit, never experienced before. The US state, however, has increased its 
financial capacity to sell various US debts.

Bringing inflation under control was a great achievement of the US Federal Reserve. Leadership of Paul Volcker was indeed decisive to lead the difficult decision process of monetary policy at the FOMC and to prioritize market uncertainty as a primary means to control over inflation. His expertise and experiences in monetary affairs were certainly an credible asset to the Federal Reserve at the time of high inflation and the declining credibility of the Federal Reserve. But his strategy towards announced monetary targets over time was not entirely new but learned from the study of German monetarist experiences, as shown in his 1978 article. His leadership shines out, compared to his prior chairman, Miller, as an obvious failure to lead the FOMC effectively. Rather the centralized process of monetary policy making within the US Federal Reserve in particular the FOMC requires organizational leadership with a high level of expertise, experience, and effective communication suitable to lead the diverse views of FOMC members across different US regions. In particular the time of turbulent US economic situations in the late 1970s required a conservative leadership of Volcker to redefine the social meaning of money. Paul Volcker was one of the outspoken conservatives to emphasize on monetarism before he was appointed as Federal Reserve chairman (Helleiner 1994). Once a monetary policy decision is made within the FOMC, the pressure and influence of delivering the policy to the outside world largely falls on Federal Reserve chairman. As the Volcker Shock draws market actors' attention into the internal process of Federal Reserve monetary policy making, Federal Reserve chairmanship become more important to lead the FOMC and communicate to the outside world effectively.

\section{CONCLUSION}

The existent IPE literature has evolved to make sense of the Volcker Shock in the development of international political economy. The first wave of IPE regards it as a post-war subjugation of the US state to the pressure of foreign states in the system of inter-states. The second wave helps us better understand the monetary shock by adding the power of international financial markets. With a focus on the relationship between labor and finance, Marxists understand the monetary event as a turning point in the relationship between labor and capital. More recent IPE scholars like Konings (2011) contributes to nuanced understanding of the monetary shock as processes of institutional configurations more functional to the US state and US financial power in international finance. Even though the waves of IPE literature have contributed to the understanding 
of the significance of the monetary event, they do not pay close attention to the particular role of the US Federal Reserve as a key actor in governing monetary disorder.

The paper has argued that the significance of Volcker Shock lies neither on a subjugation of the US state to the pressure of foreign states nor on power of international financial markets, but the transformation of the US Federal Reserve from a domestic central bank into a world monetary authority. The Volcker Shock ushered in the new beginning of the Federal Reserve's monetary governance as the inner- process of autonomous monetary policy making (monetary targeting) under the FOMC. The traditional interest rate management of the Federal Reserve was not having any impact on the dynamic force of money markets, the Federal Reserve turned to monetary targeting to dampen inflationary expectations in the public and international financial markets. The operational monetary targeting allowed the Federal Reserve to distance itself from the economic need of the US government and to draw careful attention of banks to the making of monetary policy at the FOMC meeting. Therefore, the US central bank re-established a new relationship with banks in a way that the process of FOMC monetary policy making became a new mode of monetary governance. Its direct intervention in money markets eventually extended the role of lender of last resort beyond US banks. As such, the Volcker Shock should be historicized in a way that the Federal Reserve reconfigured itself as a new relationship between the US government and international financial markets.

In mainstream economics, 'credibility' of the central bank is generally associated with independence of the state. Independent central banks are assumed to conduct policies of 'sound' money (non-inflationary policies) without interference from political pressures. In this way, scholars of IPE tend to accept the relationship between policies of sound money and market confidence or market interests, depending on political spectrum. It seems that sound money and financial market confidence is firmly established. The action of the US Federal Reserve appears to restore confidence of financial markets associated with high levels of interest rates on the credibility of the US dollar, as the second wave of the IPE tells us. However, as argued throughout this paper, the action of the US Federal Reserve aimed to create market uncertainty which provides little ground for market actors to construct interest rate calculation. Therefore, the US monetary authority was able to discipline market actors such as businesses, labours, and big banks. The assumed relationship between sound money and financial market confidence ignores the problem of state power, in particular the US monetary authority.

In other words, policies of sound money are historically more oriented toward 
empowerment of the state (the English state, for example) than the financial market (Knafo 2013). Despite that the US central bank instigated autonomous monetary policy away from the economic management of the US government, the financial capacity of the US state as a whole has been improved in a way that foreign states have continued to purchase US Treasury securities, while falling into a deep current account deficit. There is no precise separation of monetary and fiscal policies (Gabor 2016, 969). Reflecting on governing the 2007-8 global financial crisis, IPE scholars still view the role of the US central bank narrowly as international lender of last resort (McDowell 2012; Helleiner 2016). However, the US Federal Reserve not only provided dollar liquidity to foreign central banks but also transformed itself from international lender of last resort to a 'maker' or 'dealer' of global financial markets by purchasing illiquid private assets from banks and financial institutions (Buiter 2008; Mehrling 2011). The Federal Reserve even provided 'value discovery mechanisms' for illiquid private securities (Buiter 2008). The unprecedented role of the Federal Reserve can be traced back to the Volcker Shock, as the US monetary authority began to unusually expand the provision of collateral for Federal Reserve money by including any kind of financial assets. IPE scholarship on transformation of central banking is seriously needed.

\section{REFERENCES}

Allen, Paul. R. and Wilhelm, William. J. 1998. "The Impact of the 1980 Depository Institutions Deregulation and Monetary Control Act on Market Value and Risk: Evidence from the Capital Markets." Journal of Money, Credit and Banking 20(3), 364-380.

Amato, M and Fnatacci, L . 2012. The End of Finance. Cambridge: Polity Press.

Andrews, David. M. 2016. "Monetary Power and Monetary Statecraft" In David Andrews ed., International Monetary Power. Ithaca: Cornell University Press, 7-28.

Axilrod, Stephen. H. 2011. Inside the Fed: Monetary Policy and Its Management, Martin through Greeespan to Bernake. Cambridge, Massachusetts: The MIT Press.

Bartels, Andrew. H. 1985. "Volcker's Revolution at the Fed." Challenge September-October, 35-42

Bell, Stephanie. 2001. "The role of the state and the hierarchy of money." Cambridge Journal of Economics 25(2), 149-63. 
Bank for International Settlement. 1980. Annual Report. . 1981. Annual Report. 1982. Annual Report.

Blinder, Alan. S. 1998. Central Banking in Theory and Practice. London: The MIT Press.

Board of Governors of the Federal Reserve System (U.S.). 1979. "December 1979."

Buiter, Willem. H. 2008. Central banks and financial crises, Discussion Paper No 619. Available at http://eprints.lse.ac.uk/24438/ (accessed September 2018).

Burns, Arthurs. F. 1987. "The Anguish of Central Banking." Federal Reserve Bulletin September, 687-698.

Cerny, Philip. G. 1993a. "The deregulation and re-regulation of financial markets in a more open world" In Philip G. Cerny ed., Finance and World Politics: Markets, Regimes and States in the Post-Hegemonic Era. Cambridge: Edward Elgar.

. 1993b. "American decline and the emergence of embedded financial orthodoxy" In Philip G. Cerney ed., Finance and World Politics: Markets, Regimes and States in the Post-Hegemonic Era. Cambridge: Edward Elgar.

Cohen, Benjamin. J. 1971. The Future of Sterling as an International Currency. London. Macmillan St Martin's Press. . 2006. "The Macrofoundations of Monetary Power" In David Andrews ed., International Monetary Power. Ithaca: Cornell University Press.

Dale, Richard. 1984. The Regulation of International Banking. Cambridge: Woodhead-Faulkner.

Deane, Marjorie and Pringle, Robert. 1994. The Central Banking. New York: Penguin Books.

De Cecco. 1987. Financial Innovation and Monetary Theory In M. De Cecco ed., Changing Money: Financial Innovation in Developed Countries. Oxford: Basil Blackwell.

Dufey, G and Giddy, I. 1994. The International Money Market. New Jersey: Prentice-Hall.

Dumeni, Gerard and Levy, Dominique. 2004. Capital Resurgent: Roots to the Neoliberal Revolution. Cambridge, MA: Harvard University Press.

Duncan, Richard. 2005. The Dollar Crisis: Causes, Consequences, Cures. Singapore: John Wiley \& Sons(Asia) Pte Ltd.

Eichengreen, Berry. 2011. Exorbitant Privilege: The Rise and Fall of the Dollar 
and the Future of the International Monetary System. Oxford: Oxford University Press.

Einzig, Paul and Quinn, Brian. S. 1977. The Euro-dollar System. London: Macmillan.

Federal Reserve Bulletin (December 1979). Available at https://home. heinonline.org/titles/Law-Journal-Library/Federal-Reserve-Bulletin (accessed May 2019)

.1981. "March 1981." Federal Reserve Bulletin (March 1981). Available at https://home.heinonline.org/titles/Law-Journal-Library/FederalReserve-Bulletin (accessed May 2019).

.1962. "Transcripts March.” Federal Open Market Committee (March 1962). Available at https://www.federalreserve.gov/monetarypolicy/ fomc_historical_year.htm/(accessed April 2019)

. 1979. "Transcripts October." Federal Open Market Committee (October 1979). Available at https://www.federalreserve.gov/ monetarypolicy/fomc_historical_year.htm (accessed April 2019) . 1980. "Transcripts February." Federal Reserve Open Market Committee (February 1980). Available at https://www.federalreserve. gov/monetarypolicy/fomc_historical_year.htm (accessed April 2019) .1980. "Transcripts Mach." Federal Reserve Open Market Committee (March 1980). Available at https://www.federalreserve.gov/ monetarypolicy/fomc_historical_year.htm (accessed April 2019) .1980. "Transcripts April." Federal Open Market Committee (April 1980). Available at https://www.federalreserve.gov/monetarypolicy/ fomc_historical_year.htm (accessed April 2019) .1980. "Transcripts September." Federal Open Market Committee (September 1980). Available at https://www.federalreserve.gov/ monetarypolicy/fomc_historical_year.htm (accessed April 2019) . 1981. "Transcripts February." Federal Open Market Committee (February 1981). Available at https://www.federalreserve.gov/ monetarypolicy/fomc_historical_year.htm (accessed April 2019) .1982. "Transcripts March.” Federal Open Market Committee (March 1982). Available at https://www.federalreserve.gov/monetarypolicy/ fomc_historical_year.htm (accessed April 2019) .1982. "Transcripts May." Federal Open Market Committee (May 1982). Available at https://www.federalreserve.gov/monetarypolicy/ fomc_historical_year.htm (accessed April 2019) . 1982. "Transcripts June-July." Federal Open Market Committee (June-July 1982). Available at https://www.federalreserve.gov/ 
monetarypolicy/fomc_historical_year.htm (accessed April 2019)

Fisher, Stanley. 1994. "Modern central banking” In Forrest Capie et al ed., The Future of Central Banking. Cambridge: Cambridge University Press.

Fridle, Edward. J. 1979-80. "The Debate over Regulating the Eurocurrency Markets." Federal Reserve Bank of New York Quarterly Review 4(4), 11-20.

Gabor, Daniela. 2016. "The (impossible) repo trinity: the political economy of repo markets." Review of International Political Economy 23(6), 9671000.

Gerdesmeier, Dieter et al. 2007. "The Eurosystem, the U.S Federal Reserve, and the Bank of Japan: Similarities and Differences." Journal of Money, Credit and Banking 39 (7), 1785-1819.

Goodfriend, Marvin. 1986. "Monetary mystique: Secrecy and central banking." Journal of Monetary Economics 17(1), 62-92.

Gill, Stephen. 1993. "Global finance, monetary policy and cooperation among the Group of Seven, 1944-92" In Philip C. Cerny ed., Finance and World Politics. Aldershot: Edward Elgar.

Gilpin, Robert. 1987. The Political Economy of International Relations, Princeton: Princeton University Press.

Greider, William. 1987. Secrets of The Temple: How the Federal Reserve Runs the Country. New York: Simon \& Schuster Paperbacks.

Guttentag, Jack and Herring, Richard. 1983. "The Lender-of-Last-Resort Function in an International Context." Essays in International Finance no. 151. Princeton: Department of Economics, Princeton University.

Hager, Sandy. B. 2012. "Investment Bank Power and Neoliberal Regulation: From the Volcker Shock to the Volcker Rule." In Henk Overbeek and Bastiaan van Apeldoorn ed., Neoliberalism in Crisis. Basingstoke, UK: Palgrave Macmillan.

Hakkio, Craig. S. 1995. "The U.S. Current Account: The Other Deficit." Economic Review, Federal Reserve Bank of Kansas City, Third Quarter, 1-24.

Hall, Peter. 1993. "Policy paradigms, social learning, and the state: the case of economic policymaking in Britain." Comparative Politics 25(3): 275296.

Hall, Rodney. B. 2008. Central Banking as Global Governance: Constructing Financial Stability. Cambridge. UK: Cambridge University Press.

Hawley, James. P. 1984. "Protecting Capital from Itself: U.S Attempts to Regulate the Eurocurrency System.” International Organization 38(1), $131-65$. 
Helleiner, Eric. 1994. States and the Re-emergence of Global Finance, Ithaca: Cornell University Press.

. 2016. "Still an extraordinary power after all these years: the US and the global financial crisis of 2008." In Randall G. Germain ed., Susan Strange and the Future of Global Political Economy. Abingdon: Routledge.

Helleiner, Eric and Kirshner, Jonathan. 2014. "The Politics of China's International Monetary Relations." In E. Helleiner and J. Kirshner ed., The Great Wall of Money. Ithaca, NY: Cornell University Press.

Hobson, John. M. 1997. The Wealth of States: A Comparative Sociology of International Economic and Political Change, Cambridge: Cambridge University Press.

Ingham, Geoffrey. 2004. The Nature of Money. Cambridge: Polity Press.

Johnson, Peter. A. 1998. The Government of Money: Monetarism in Germany and the United States. Ithaca: Cornell University Press.

Jones, David. M. 1991. The Politics of Money: The Fed under Alan Greenspan. New York: New York Institute of Finance.

Kane, E. J. 1979. "The Three faces of commercial bank liability management." In Michael $\mathrm{P}$ et al ed., The Political Economy of Policy-Making essays in Honor of Will E Mason. Beverly Hills: Sage Publications.

Key, Sydney. J. 1982. "International Banking Facilities." Federal Reserve Bulletin October, 565-77.

Kindleberger, Charles. P. 1967. "The Politics of International Money and World Language." Essays in International Finance No. 61 Princetion, NJ: Princeton University.

. 1978. Manias, Panics and Crashes: A History of Financial Crises, London: Macmillan.

Kirshner, Jonathan. 2003. Money is politics. Review of International Political Economy 10(4), 645-60.

Keenen, Peter B. 2002. "The Euro Versus the Dollar: Will There Be a Struggle for Dominance" Journal of Policy Modeling 24, 307-314.

Kelly, Janet. 1977. Bankers and Borders: The Case of American Banks in Britain. Cambridge: Ballinger.

Keohane, Robert. 1982. "Inflation and the Decline of American Power." In Ray Lombra and Bill Witte ed., The Political Economy of International and Domestic Monetary Relations. Ames: Iowa State University Press.

Knafo, Samuel. 2013. The Making of Modern Finance: Liberal governance and the gold standard. London: Routledge.

Konings, Martijin. 2008. "The institutional foundations of US structural power 
in international finance: From the re-emergence of global finance to the monetarist turn”. Review of International Political Economy 15(1), 3561.

. 2011. The Development of American Finance, Cambridge: Cambridge University Press.

Krasner, Stephen D. 1978. "United States Commercial and Monetary Policy: Unraveling the Paradox of External Strength and Internal Weakness.

In Peter J. Katzenstein ed., Between Power and Plenty, Madison: The Universit of Wisconsin Press.

Kreicher, Lawrence. L. 1982. "Eurodollar Arbitrag. Federal Reserve Bank of New York Quarterly Review 7, 10-22.

Krippner, Greta. R. 2007. "The making of US monetary policy: Central bank transparency and the neoliberal dilemma." Theory and Society 36(6), 477-513. . 2011. Capitalizing on Crisis: The Political Origins of the Rise of Finance. London: Harvard University Press.

Lim, Kyuteg. 2019. "Why, When, and How the US Dollar Was Established as World Money." Peace Studies 27 (2). Forthcoming.

Niehans, J and Hewson, J. 1976. "The Eurodollar Market and Monetary Theory". Journal of Money, Credit and Banking 8(1), 1-27.

Norville, Elizabeth. 1998. "The "Illiberal" Roots of Japanese Financial Regulatory Reform” In L.E. Carlie and M.C. Tilton ed., Is Japan Really Changing Its Ways" Regulatory Reform and the Japanese Economy. Washington D.C: Brookings Institution Press, 111-141.

MacDowell, Daniel. 2012. "The US as "sovereign international last-resort lender": The Fed's currency swap programme during the Great Panic of 2007-09." New Political Economy 17(2), 157-178.

Meltzer, Allan. H. 2009. A History of the Federal Reserve. Vol 2. Chicago: University of Chicago Press.

Mayer, Martin. 2001. The FED: The Inside Story of How the World's Most Powerful Financial Institution Derives the Markets. New York: The Free Press.

McKenzie, George. W. 1981. The Economics of the Euro-Currency System. London: Macmillan.

Mendelsohn, Stefan. 1980. Money on the Move: The Modern International Capital Market, New York: McGraw-Hill Book Company.

Mehrling, Perry. 2011. The New Lombard Street: How the Fed Became the Dealer of Last Resort. Princeton: Princeton University Press.

Oatley, Thomas. 2012. International Political Economy. London: Routledge. 
Odell, John. S. 1982. US International Monetary Policy: Markets, Power and Ideas as Sources of Change. Princeton: Princeton University Press.

Panitch, Leon and Gindin, Sam. 2008. "Finance and American Empire." In Leo Panitch and Martijin Konings ed., American Empire and the Political Economy of Global Finance. Basinstoke: Palgrave Macmillan.

Schwartz, Herman. 2014. "Global imbalances and the international monetary system" In T. Oatley and W. K. Winecoff eds., Handbook of the International Political Economy of Monetary Relations. Cheltenham: Edward Elgar.

Seabrooke, Leonard. 2001. US Power in International Finance: The Victory of Dividends, New York: Palgrave.

Smith, David. 1987. The Rise and Fall of Monetarism. Hanmondsworth: Penguin.

Solomon, Robert. 1977. The International Monetary System, 1945-1976: An insider's view. New York: Harper and Row.

Spero, Joan. E. 1980. The Failure of the Franklin National Bank: Challenge to the International Banking System, New York: Columbia University Press.

Strange. Susan. 1986. Casino Capitalism. Oxford: Basil Blackwell.

Swoboda, Alexander. K. 1968. "The Euro-Dollar Market: An Interpretation." Essays in International Finance. Princeton, NJ: Princeton University.

Timberlake, Richard. H. 1985. "Legislative Construction of the Monetary Control Act of 1980". The American Economic Review 75(2), 99-102

Treaster, Joseph. B. 2004. Paul Volcker: The Making of A Financial Legend. New Jersey: John Wiley \& Sons.

Versluysen, Eugene. L. 1981. The Political Economy of International Finance. New York: St. Martin's Press.

Volcker, Paul. 1978. "The Role of Monetary Targets in an Age of Inflation." Journal of Monetary Economics 4(2), 329-339.

Wallich, Henry. C. 1979. "Why the Euromarket Needs Restraint." Columbia Journal of World Business 14(3), 21-24.

Walter, Andrew. 1991. World Power and World Money: The Role of Hegemony and International Monetary Order. London: Harvest Wheatsheaf.

Woolley, John. T. 1984. Monetary Politics: The Federal Reserve and the Politics of Monetary Policy. London: Cambridge University Press.

Wray, Randall. L. 1998. Understanding Modern Money. Cheltenham: Edward Elgar. 


\section{APPENDIX}

Figure A1. U.S. Current Account Deficit
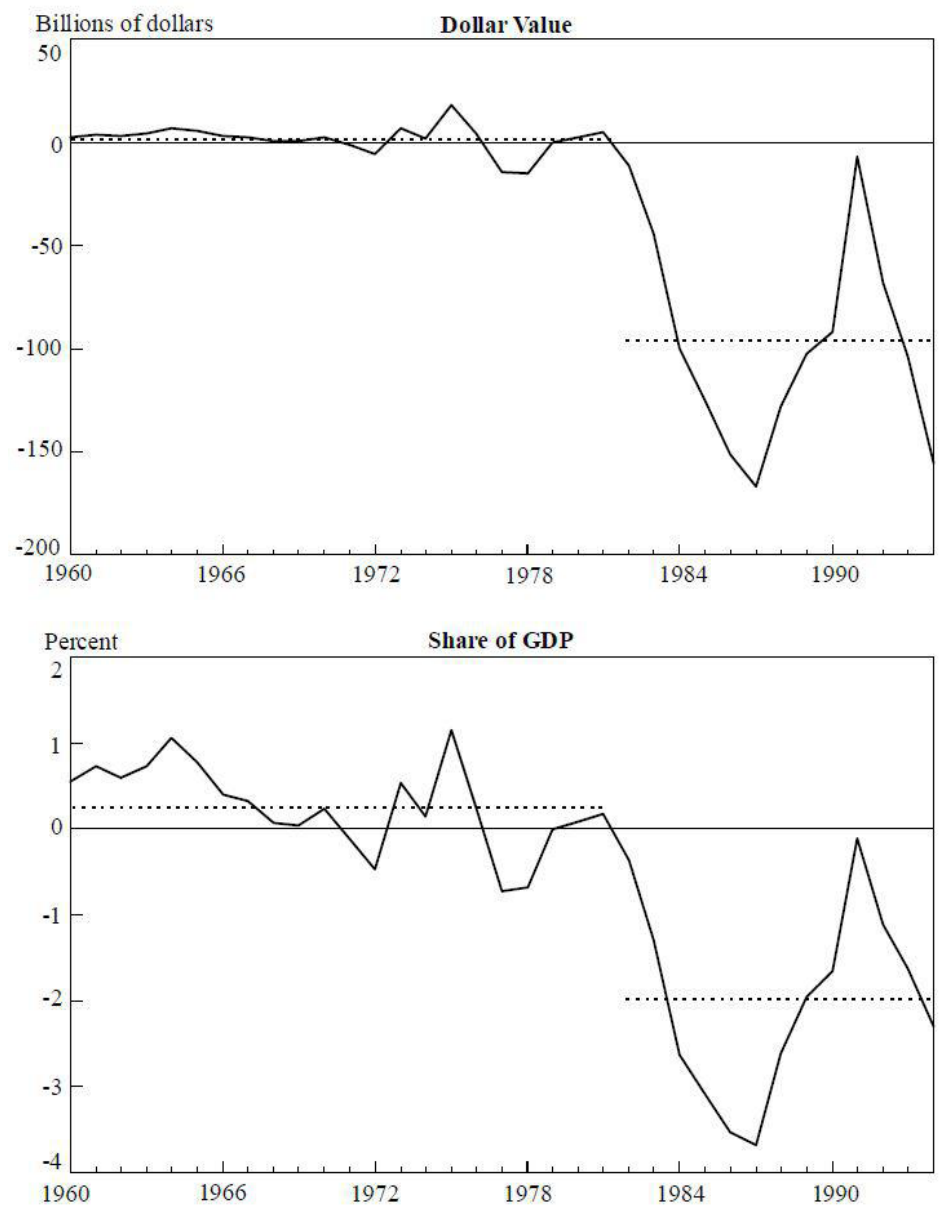

Note: The dotted line equals the average current account surplus from 1960 to 1981, and the average current account deficit from 1982 to 1994.

Source: U.S. Department of Commerce, drawn on Hakkio (1995, 13). 
